\title{
STUDIES ON A CASE OF ESSENTIAL HYPERLIPEMIA. BLOOD LIPIDS, WITH SPECIAL REFERENCE TO THE COMPOSITION AND METABOLISM OF THE SERUM GLYCERIDES BEFORE, DURING AND AFTER THE COURSE OF A VIRAL HEPATITIS
}

\author{
BY LARS A. CARLSON AND BÖRJE OLHAGEN
}

\author{
(From the Department of Internal Medicine, Karolinska sjukhuset, and the King Gustaf $V$ \\ Research Institute, Stockholm, Sweden)
}

(Submitted for publication September 15, 1958; accepted January 2, 1959)

The clinical course of the syndrome of essential hyperlipemia is characterized by cutaneous xanthomas, hepatosplenomegaly and recurrent attacks of abdominal pain. The diagnosis is confirmed by the milky appearance of a fasting serum sample. It is interesting to note that 100 years ago Addison and Gull (1) described xanthoma tuberosum as well as xanthoma tendinosum. Seventy-five years were to elapse, however, before Bürger and Grütze in 1932 (2) associated the symptoms and objective findings in this disease and described the first case of essential hyperlipemia. Since then more than 50 cases have been reported in the literature; from Sweden, 10 cases were presented by Malmros, Swahn and Truedsson in 1954 (3).

Bürger and Grütze (2) not only described the syndrome of essential hyperlipemia, but also made important contributions as regards the pathogenesis and therapy of the disease. By alimentary fat load they demonstrated the existence of "Dauerlipoidemi." Treatment with a low-fat diet resulted in disappearance of the cutaneous manifestations and of the hepatosplenomegaly. These findings have since been discussed and confirmed by several writers (4-7). Thannhauser and Stanley (5) fed olive oil labeled with $\mathrm{I}^{131}$ to patients with essential hyperlipemia and to normal subjects. They found increased concentration and prolonged retention of $\mathrm{I}^{131}$ in the blood of the former group. Havel (8) studied three brothers with essential hyperlipemia who had a prolonged retention of glycerides in the blood stream after a fatty meal. He was able to demonstrate an almost complete deficiency of the heparin-induced lipemia clearing factor. It was suggested that the cause of the hyperlipemia in these cases apparently was related to the metabolism of exogenous glycerides.

Schrade, Becker and Böhle (6) have, however, pointed out that completely normal blood lipid levels cannot be obtained in essential hyperlipemia by dietary means. They concluded that there is also a faulty metabolism of endogenous glycerides, a theory which has also been advanced by Schettler, Eggstein and Jobst (9).

In view of these observations it seems probable that in essential hyperlipemia there is some defect in the removal of lipids from the blood stream. The following report concerns some studies on the metabolism of the serum glycerides in one case of essential hyperlipemia including the changes in the blood lipid pattern during the course of a viral hepatitis.

\section{MATERIAL AND METHODS}

Case history. The patient was a 38 year old male without known heredity of interest. At the age of 27, xanthoma tuberosum appeared on the elbows. In 1950 a plastic operation was performed on the elbows. In 1952 he was admitted to the medical department of this hospital. Physical examination then revealed a well-nourished, apparently healthy man, with xanthoma tuberosum on the elbows, the volar aspects of the fingers, and the gluteal region. On the left Achilles tendon a xanthoma the size of a walnut was palpable. Standard analyses of blood and urine gave normal results. The serum cholesterol was $480 \mathrm{mg}$. per $100 \mathrm{ml}$; the total lipids, 1,880 $\mathrm{mg}$. per $100 \mathrm{ml}$. (gravimetric analysis); and the fasting serum had a milky appearance. The basal metabolic rate was -15 per cent. An oral glucose tolerance test was slightly pathologic. Substitution therapy was given with a thyroxin preparation (Laevoxin-Nyco), $0.1 \mathrm{mg}$. daily, which he has continued to take. He was readmitted to the hospital in November, 1956, for investigation of lipid metabolism. His only complaint was slight pain at times in the cutaneous xanthomas. Apart from these, physical examination revealed nothing pathologic. The liver and spleen were of normal size on roentgenographic examina- 
TABLE I

Composition of the serum lipids and lipoproteins

\begin{tabular}{|c|c|c|c|c|c|c|c|c|}
\hline \multirow[b]{2}{*}{ Cholesterol } & \multirow[b]{2}{*}{$\begin{array}{l}\text { Phospho- } \\
\text { lipids }\end{array}$} & \multicolumn{4}{|c|}{ Glycerides } & \multirow[b]{2}{*}{$\begin{array}{l}\text { Unesterified } \\
\text { fatty acids }\end{array}$} & \multicolumn{2}{|c|}{$\alpha$-Lipoproteins } \\
\hline & & Total & $\begin{array}{c}\text { Triglyc- } \\
\text { erides }\end{array}$ & $\begin{array}{l}\text { Diglyc- } \\
\text { erides }\end{array}$ & 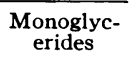 & & Cholesterol & $\begin{array}{c}\text { Phospho- } \\
\text { lipids }\end{array}$ \\
\hline $\begin{array}{c}m g . / 100 \mathrm{ml} . \\
1,040\end{array}$ & $\begin{array}{c}m g . / 100 \mathrm{ml} \\
810\end{array}$ & 24.3 & $23.0^{m \Lambda}$ & 1.1 & 0.1 & $\begin{array}{c}m E q . / L . \\
0.97\end{array}$ & $\begin{array}{c}m g . / 100 \mathrm{ml} . \\
38\end{array}$ & $\begin{array}{c}m g . / 100 \mathrm{ml} \\
82\end{array}$ \\
\hline
\end{tabular}

tion. The BMR was +3 per cent. The serum bilirubin was $0.3 \mathrm{mg}$. per $100 \mathrm{ml}$. Paper electrophoresis was normal. He left the hospital in December. Afterwards his blood lipids were analyzed every second or third week. He was feeling quite well until Feb. 28, 1957, when he developed pain in the epigastrium. For the first three days, the pain was rather intense, sometimes radiating up under both shoulders. The pain then disappeared and the patient complained only of occasional aching under his right costal margin. At the same time, he suffered from mild fatigue and anorexia. However, all the time he was eating fat as usual. His temperature was slightly elevated, being about $37.2^{\circ} \mathrm{C}$. in the mornings. No discoloration of urine or feces had been noted. On March 12 he was hospitalized with a tentative diagnosis of a viral hepatitis. The examination revealed a slightly jaundiced man. Some palpatory tenderness was present in the upper abdomen. Otherwise, the physical examination was quite normal. Weight was $72.4 \mathrm{Kg}$. (3 months earlier, $74.7 \mathrm{Kg}$.). Laboratory findings were a leukopenia (2,300 W.B.C.), normal differential count, normal hemoglobin and slightly increased sedimentation rate. The Meulengracht index was 1:24 on March 12 . The subsequent clinical course has been summarized in Table III. Treatment consisted of bed rest without dietary restrictions and injections of $\mathrm{B}$-vitamins $\left(\mathrm{B}_{1}, \mathrm{~B}_{2}\right.$ and $\left.\mathrm{B}_{6}\right)$.

Extraction and purification of blood lipids. Venous blood samples were allowed to clot for about 1 hour at room temperature. In the heparin-induced clearing experiments, heparin was added to the blood samples in amounts sufficient to inhibit the clearing reaction (10), and the plasma was extracted as soon as possible. Serum or plasma was extracted with chloroform-methanol $(2: 1$, $\mathrm{v} / \mathrm{v})$, the extract purified by washing and then subjected to chromatography on silicic acid as described earlier $(11,12)$.

Glyceride determinations. The glyceride concentration was determined by estimation of glyceride glycerol (11, 12). Tri-, di- and monoglycerides were separated on silicic acid according to Borgström on a microscale (11).

Cholesterol determination. Total cholesterol was determined by a slightly modified Tschugaeff reaction on saponified samples (14).

Phospholipids. Lipid phosphorus was analyzed by wet combustion and converted to phospholipids by a factor of 25 .

Unesterified fatty acids. The free fatty acids in the lipid extract were separated off by an ion exchanger according to Borgström (13), converted to methyl esters and estimated by means of the hydroxamic acid reaction (15).

Lipoprotein separation. The serum lipoproteins were separated chromatographically on glass powder (16). Only two major fractions were obtained, viz. the $\alpha$-lipoproteins and the $\beta$-lipoproteins plus the very low density lipoproteins. Cholesterol and phospholipids were determined on chloroform-methanol extracts of the separated fractions.

In vitro clearing experiment. Partially purified postheparin clearing factor was prepared from human plasma according to Nikkilä (17). Normal chylomicrons after a fatty meal and the patient's chylomicrons were separated by centrifugation at serum density of $25,000 \times \mathrm{G}$, washed twice and recentrifuged at $25,000 \times \mathrm{G}$. The chylomicrons were incubated with the clearing factor preparation at $\mathrm{pH} 7.4$ in a 5 per cent albumin solution. Aliquots were pipetted off at different time intervals directly into chloroform-methanol and the glyceride concentration was estimated as described above.

Glucose tolerance test. One hundred $\mathrm{Gm}$. of glucose was given in the fasting state and the blood sugar determined at half hourly intervals (18).

Liver function tests. The icteric index according to Meulengracht was estimated as a measure of the degree of jaundice (19). The upper normal limit is 1:6. Alkaline phosphatase was performed according to Buch and Buch $(20)$, the normal value being below 9 units. The thymol test was done according to McLagan (21), a value above 4 units being pathological.

Transfusion experiment. From the patient's fasting blood plasma, with a glyceride concentration of $9.85 \mathrm{mM}$ per L., $250 \mathrm{ml}$. was transferred to a healthy volunteer who had been fasting for about 16 hours and continued fasting throughout the experiment. The transfusion was given at a constant rate and was completed within 20 minutes. No untoward reaction was observed.

\section{RESULTS}

The composition of the serum lipid and lipoproteins when the patient was admitted in November, 1956 , is shown in Table I. Total lipids amounted to about 4 per cent. Cholesterol and phospholipids were increased about four times above normal levels, while the glycerides were increased about 20 -fold. The amount of lower glycerides was higher than normal, but the percentage composi- 


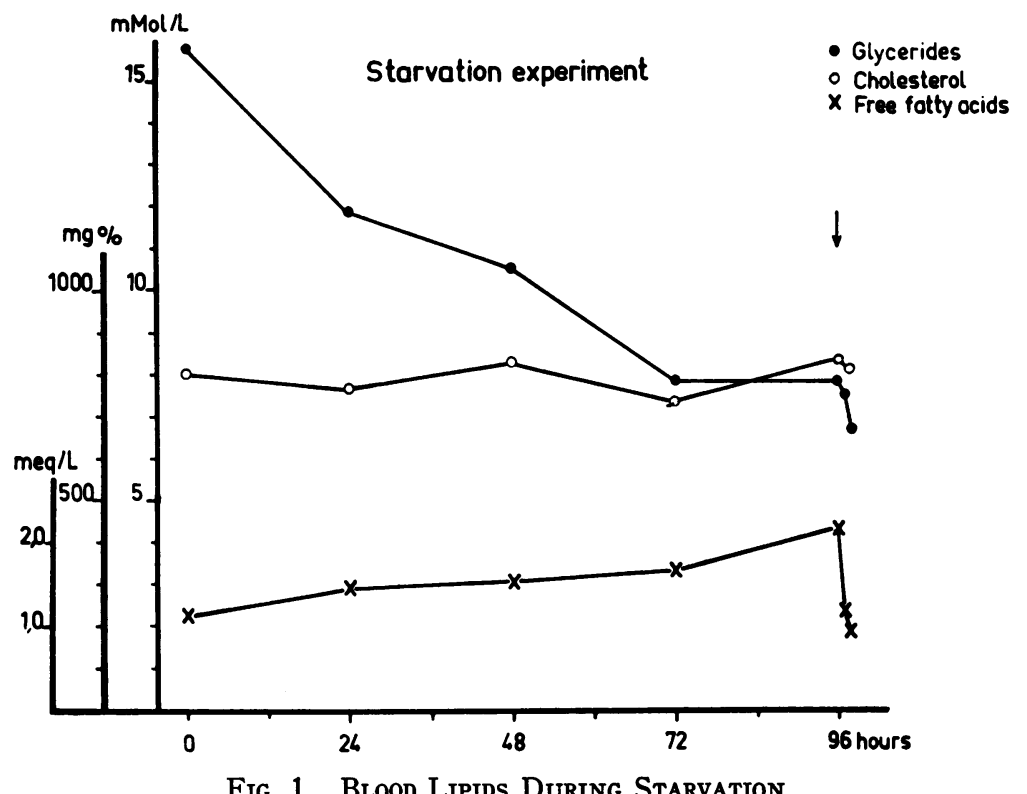

Glyceride concentration is given in $\mathrm{mM}$ per L.; cholesterol, in mg. per 100 $\mathrm{ml}$; and free fatty acids, in mEq. per L.

tion showed no major deviation from the normal (11). The content of unesterified fatty acids was slightly above normal level, which in 10 normal persons was found to be $0.69 \pm 0.10 \mathrm{mEq}$. per $\mathrm{L}$. with the present technique (15). The $\alpha$-lipoproteins, on the other hand, were present in normal amounts and exhibited a normal cholesterol/ phospholipid ratio. In the patient's available relatives

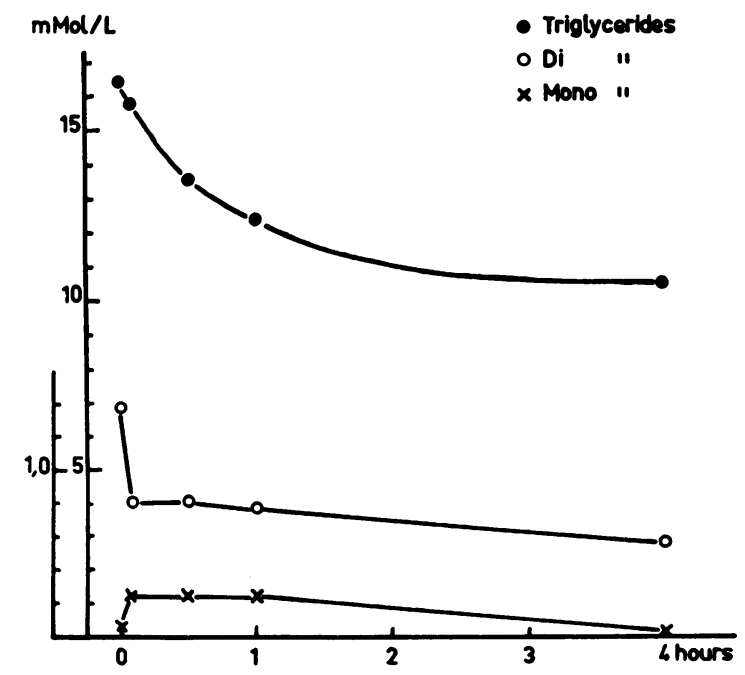

Fig. 2. Response of the Serum Glycerides to a Single IntRavenous Heparin InJeCtion

The partial glycerides are referred to the enlarged scale. (father and father's sister) the serum lipids were within normal range.

Starvation experiment. The patient starved for 96 hours, ingesting only mineral water and vitamins. The variations of the serum lipids during the starvation period are presented in Figure 1. The experiment was terminated by the oral administration of $100 \mathrm{Gm}$. of glucose (indicated by the arrow in Figure 1). Within two hours after the administration of glucose, the unesterified

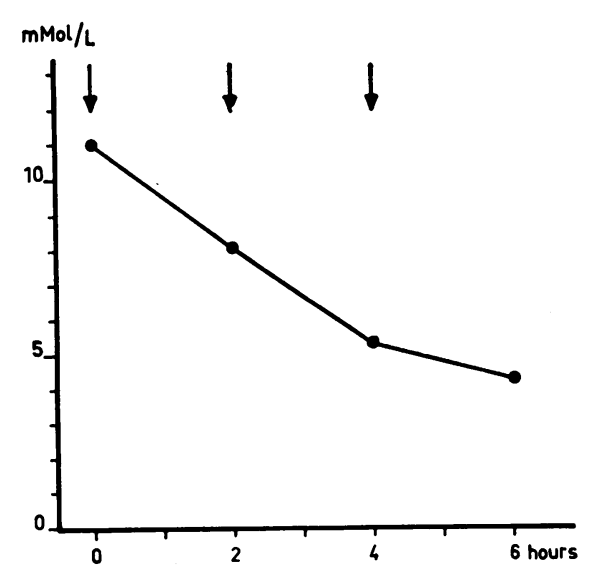

Fig. 3. Response of the Serum Glycerides to Repeated Intravenous Heparin Injections

Fifty mg. of heparin was given at the points indicated by arrows. 
fatty acids had diminished from 2.0 to $0.9 \mathrm{mEq}$. per L. and the glycerides from 8 to $6 \mathrm{mM}$ per L.

Heparin tests. These experiments were performed in two ways. First, the effect of a single intravenous injection of $50 \mathrm{mg}$. of heparin was studied by analysis of the concentration of tri-, di- and monoglycerides at various time intervals (Figure 2), and second, the concentration of total serum glycerides was followed after repeated intravenous injection of $50 \mathrm{mg}$. of heparin (Figure 3).

In vitro clearing experiment. The results obtained when normal chylomicrons and chylomicrons isolated from the patient's serum were in-

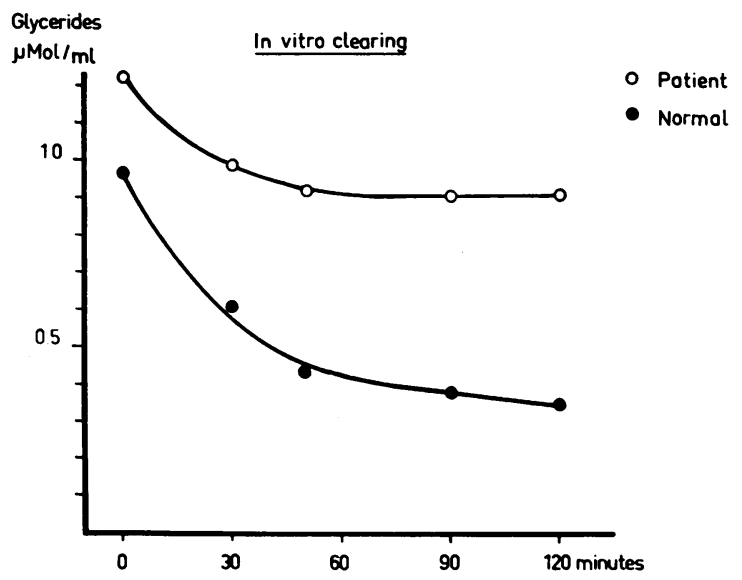

Fig. 4. In Vitro Clearing of the Patient's ChyLOMICRONS AND NoRmal Chylomicrons UPON INCUBAtion with Partly Purified Postheparin Clearing FACTOR

cubated with partly purified postheparin clearing factor are given in Figure 4. It is quite evident that the patient's chylomicrons were not as readily attacked by the clearing factor preparation as were normal chylomcirons. Addition of more albumin did not influence the rate of hydrolysis.

Transfusion experiment. Figure 5 shows the glyceride concentration in the recipient's plasma during the transfusion experiment. To permit study of the kinetics of glyceride removal from the blood stream, the values were plotted on a logarithmic scale (Figure 6). The resulting curve was resolved into two exponential functions, number one being extrapolated from the curve best fitting the experimental points. The half-lives for the two functions were about 1,100 and $30 \mathrm{~min}$ utes, respectively.

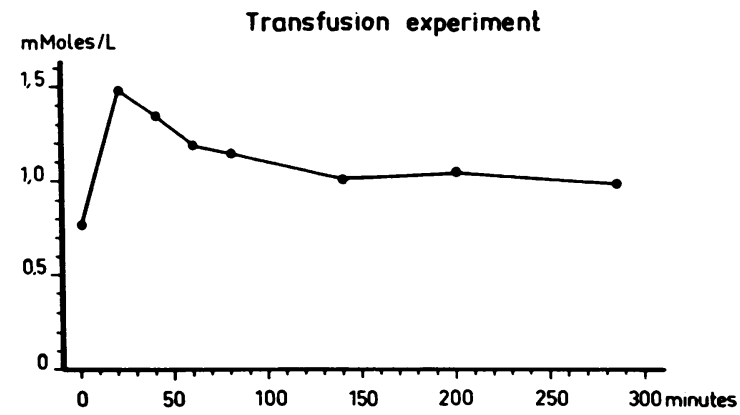

Fig. 5. Serum Glycerides in a Normal Healthy Adult After Transfusion of Plasma from the HyPERLIPEMIC SUBJECT

The transfusion began at time 0 and ended at 20 minutes.

Glucose tolerance test. The blood glucose response to oral glucose is given in Table II.

Blood lipids during viral hepatitis. The clinical course of the hepatitis has been summarized in Table III. The serum lipids during the course of, and the recovery from, the hepatitis can be followed in Figure 7. The fasting serum sample on admission (March 12) was almost clear in contrast to the earlier creamy appearance of fasting specimens. It is of interest to point out that

TABLE II

Oral glucose tolerance test

\begin{tabular}{lcccccc}
\hline \hline Time*......... & $8: 00$ & $8: 30$ & $9: 00$ & $9: 30$ & $10: 00$ & $10: 30$ \\
\hline $\begin{array}{c}\text { Blood sugar } \\
(\mathrm{mg} . / 100 \mathrm{ml} .)\end{array}$ & 105 & 248 & 265 & 235 & 140 & 96 \\
\hline
\end{tabular}

${ }^{*} 100 \mathrm{Gm}$. of glucose was given at 8:00.

Tronsfusion Experiment

Removol rote of the glycerides

Concentrotion increose

$\mathrm{mMol} / \mathrm{L}$

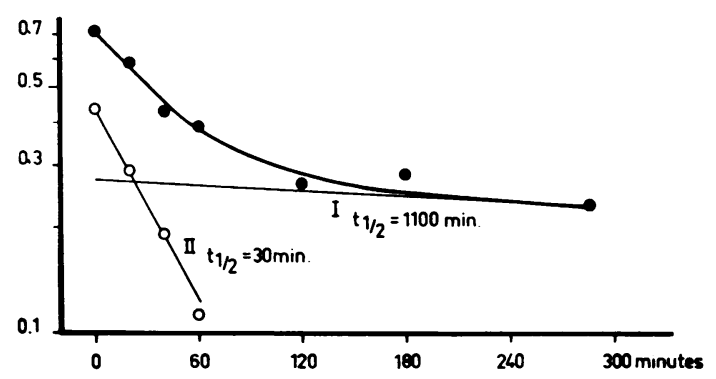

Fig. 6. Semilogarithmic Diagram from the TransFUSION EXPERIMENT (Figure 5)

The transfusion was finished at time 0 . The concentration was calculated from the pretransfusion level. 
TABLE III

Clinical course and some laboratory data during the course of a viral hepatitis

\begin{tabular}{|c|c|c|c|c|c|c|c|c|}
\hline Date.............. & $12 / 3$ & $13 / 3$ & $20 / 3$ & $27 / 3$ & $3 / 4$ & $10 / 4$ & $29 / 4$ & $27 / 5$ \\
\hline $\begin{array}{l}\text { General } \\
\text { appearance }\end{array}$ & & $\begin{array}{l}\text { Jaundiced, } \\
\text { tired }\end{array}$ & $\begin{array}{l}\text { Jaundiced, } \\
\text { tired }\end{array}$ & $\begin{array}{l}\text { Improved, } \\
\text { not so } \\
\text { tired }\end{array}$ & $\begin{array}{l}\text { Still more } \\
\text { improved, } \\
\text { out of bed } \\
2 \mathrm{hr} \text { a day }\end{array}$ & $\begin{array}{l}\text { Only } \\
\text { slightly } \\
\text { tired }\end{array}$ & $\begin{array}{l}\text { Has left the } \\
\text { hospital } \\
(13 / 4)\end{array}$ & Excellent \\
\hline Weight (Kg.) & 72.4 & & 72.0 & 72.5 & 74.1 & 73.1 & & \\
\hline $\begin{array}{l}\text { Morning tem- } \\
\text { perature }\left({ }^{\circ} C .\right) \\
\text { Meulengracht } \\
\text { index }\end{array}$ & & 37.1 & 37.0 & 37.0 & 36.6 & 36.6 & & \\
\hline $\begin{array}{l}\text { (Normal, }<1: 6 \text { ) } \\
\text { Thymol test units } \\
\text { Alkaline phos- }\end{array}$ & $1: 24$ & $1: 20$ & $\begin{array}{r}1: 20 \\
6\end{array}$ & $\begin{array}{r}1: 9 \\
6\end{array}$ & $\begin{array}{r}1: 8 \\
8\end{array}$ & $\begin{array}{r}1: 8 \\
8\end{array}$ & $1: 6$ & $\begin{array}{r}1: 4 \\
4\end{array}$ \\
\hline phatase, units & & 11 & 13 & 11 & 14 & 12 & 4 & 5 \\
\hline
\end{tabular}

the blood lipids had already started to decline on February 18, 10 days before any subjective symptoms had appeared. The percentage composition of partial glycerides on March 12 was normal, and the concentration of unesterified fatty acids was $0.94 \mathrm{mEq}$. per L. No clearing activity could be demonstrated in the patient's blood upon incubation of his plasma with chylomicrons. During the incubation studies no changes in optical density or in unesterified fatty acid concentration were observed.

The effect of an alimentary fat load was studied on two occasions during the illness. The fat was given in the form of cream containing 40 per cent fat. The first fat load was given after three days at the hospital when the blood lipids were still decreasing. The second fat load study was performed after one month at the hospital when the blood lipids were tending to increase. Both tests gave qualitatively similar results, as shown in Figure 8.

\section{DISCUSSION}

The typical clinical features in this case were the cutaneous xanthomas and the grossly elevated content of glycerides in fasting serum samples. The fact that the concentration of unesterified fatty acids was slightly elevated is difficult to evaluate

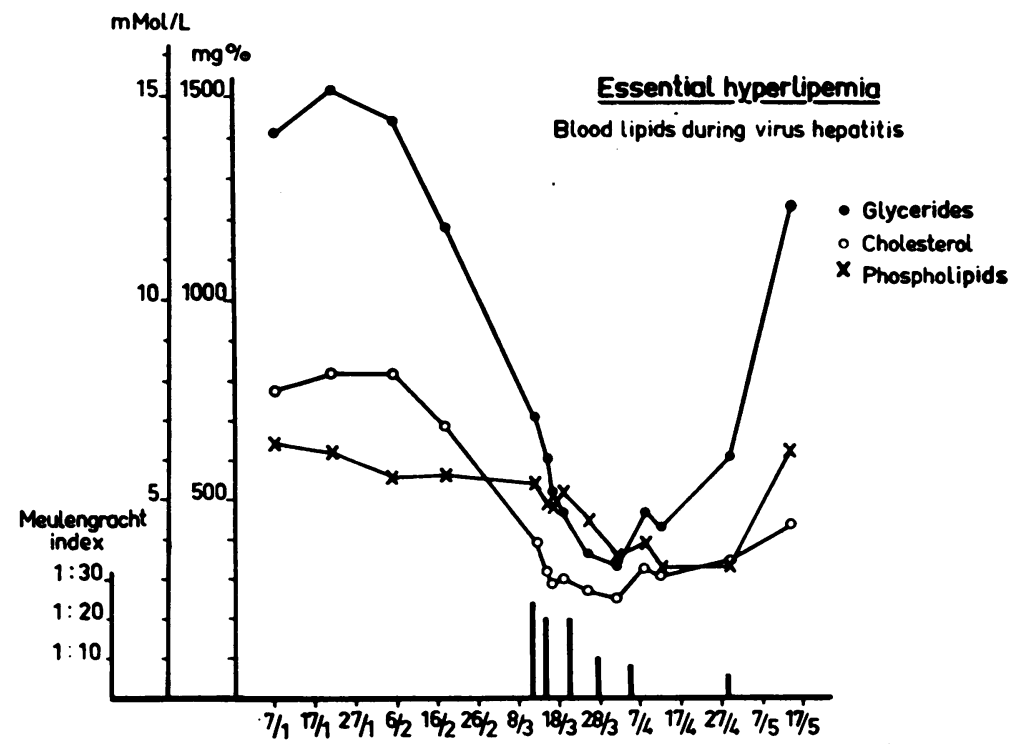

Fig. 7. Blood Lipids and Meulengracht Index During Viral Hepatitis Glyceride concentration is expressed in $\mathrm{mM}$ per L.; cholesterol and phospholipids, in $\mathrm{mg}$. per $100 \mathrm{ml}$. 


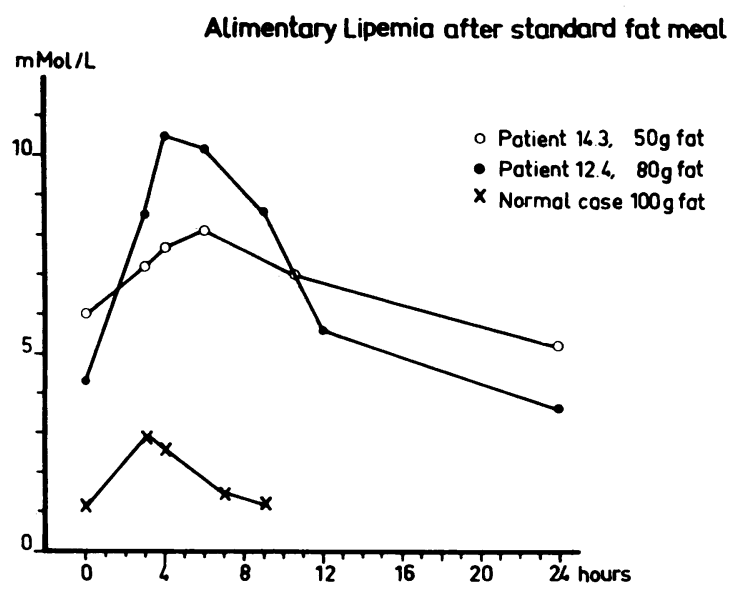

Fig. 8. Serum Glycerides After a Standard Fat Meal in the Patient at Two Different Times and in a Normal Subject

in view of the lability of this fraction. In vitro incubation of the patient's serum did not give rise to any lipolysis of significance. Normal levels of unesterified fatty acids in essential hyperlipemia were reported by Dole (22). The $\alpha$-lipoprotein concentration was normal, in contrast to the findings of Havel and Gordon (23).

Although the glycerides decreased during the three first days of starvation, the level was not reduced below $8 \mathrm{mM}$ per L. On the other hand, normal subjects starving for three days showed an increase in the serum glycerides which, however, did not exceed $1.5 \mathrm{mM}$ per L. (11). Havel and Gordon (23) studied a case of essential hyperlipemia which, during starvation with an R.Q. of 0.73 , had an essentially normal blood lipid pattern. Their interpretation was that the endogenous lipid metabolism was operating in the normal way in this patient. The findings during starvation, suggest that, in our patient, there was a faulty metabolism of endogenous glycerides.

The increase of unesterified fatty acids during the starvation period was similar to that reported for normal individuals during starvation (24). The immediate fall in this fraction after glucose feeding is on a par with earlier findings in normal subjects $(22,25)$.

Heparin administration in this case of essential hyperlipemia resulted in a reduction of the glyceride concentration. Several writers have noted this type of response in essential hyperlipemia (26-
30). Others, however, have reported absence of heparin response (8).

After a single heparin dose in our case, the reaction of the partial glycerides was the same as in normals (31). The principal feature was a decrease of triglycerides and an increase of monoglycerides. This glyceride pattern during lipemia clearing can be explained if the clearing factor primarily attacks the $\alpha$-ester bond in the glyceride molecule (32).

A considerably decreased plasma glyceride concentration was obtained when heparin was administered three times at intervals of two hours. The glyceride level then fell by about 60 per cent in six hours.

These heparin experiments showed that the patient's capacity to produce clearing-factor activity in his blood was similar to that of normal persons. Further, the mechanism for removing fatty acids-principally serum albumin-must have been intact, since otherwise an accumulation of these products of hydrolysis would necessarily have retarded, and finally inhibited, the clearing reaction.

The in vitro clearing experiment indicated that the very low density material isolated from the patient was not as readily hydrolyzed by the clearing factor preparation as were normal chylomicrons. This has been shown earlier in essential hyperlipemia from this laboratory (11). The behavior is, however, once again in contrast to that found in Havel's patients, where the chylomicrons served as an excellent substrate for the lipoprotein lipase (8).

When the glyceride increase in the transfusion experiment is plotted on a semilogarithmic scale versus time, the curve could be resolved into two exponential functions. This procedure requires the assumption that the endogenous glyceride level remained unchanged in the recipient during the experiment. In a study of the glycerides during starvation in normals, no increase was found before 39 hours (11) nor were any consistent changes observed in repeated blood samples during the early phase of starvation after an overnight fast (33). These findings seem to justify the above assumption.

The behavior of the glycerides was strikingly different from what has been reported to occur when chylomicrons are transfused to dogs (34) 
and rats (35). In these experiments the elimination from the plasma was a simple exponential function of time. Havel observed the same first order reaction for the elimination of the glycerides when a normal man was transfused with plasma from one of his patients with essential hyperlipemia (8). Eder transfused chylous ascites to a patient with carcinoma and found that the removal was first rapid, with a half-life of 15 minutes, but that there was a second and slower component with a half-life of two hours (36). The half-life of the first phase in our case is of about the same magnitude as that reported earlier in animals $(34,35)$ and man $(8,36)$. Any second phase of the magnitude observed here has not been seen when purified chylomicrons have been studied nor when hyperlipemic plasma was given to a normal individual (8). In the case of chylous ascites, on the other hand, a second phase was observed. However, the half-life for the second phase in our case was much longer.

The second slope could result either from a distribution in a second pool or from a heterogeneity of the glycerides. The magnitude of this second component of the curve, when compared to available data on the removal of chylomicrons, makes the latter view appear the most probable. If so, this glyceride fraction consisted of about 30 to 40 per cent of the transfused amount of glycerides.

The slightly pathologic glucose tolerance curve is of great interest. Similar findings have been reported earlier in essential hyperlipemia and compiled by Lever, Smith and Hurley (37). Adlersberg and Wang have described the syndrome of essential hyperlipemia, mild diabetes mellitus and severe vascular damage (38). There was, however, no evidence in this patient of any vascular disease.

The decreased glyceride level during the hepatitis is to be ascribed to a change in the metabolism of either exogenous or endogenous glycerides or both. There seems to be no reason to assume a decreased glyceride level due to a diminished fat intake as far as could be judged from the history and the eating habits during the hospital stay. Furthermore the decrease was already observed on February 18, 10 days before any subjective complaints. Similarly, a decreased intestinal absorption of fat of such a magnitude as to influence the blood glyceride level seems rather unlikely. It is known from studies in animals (39) and man (40) that in the total absence of bile 60 to 70 per cent of the alimentary fat is absorbed. Furthermore, the amount of fat in feces during hepatitis is directly correlated with the bilirubinemia (41, 42 ), and in our case the glycerides decreased before the jaundiced stage and continued to decrease when the bilirubinemia leveled off. Interestingly, no significant rise in blood lipids during fat absorption was observed in dogs with bile fistula (43). In bile fistula rats Borgström found that, at the most, 25 per cent of the absorbed fat was transported via the thoracic duct lymph (44). However, a significant rise in the serum glycerides was seen in our patient after a fatty meal during the hepatitis. Thus, the liver disease does not seem to have exerted any significant influence on the resorptive phase of the metabolism of exogenous glycerides. It has not been possible to quantify the elimination phase, although the resorption curves in Figure 8 suggest that this phase was quantitatively of the same magnitude when the glycerides were dropping sharply as when they had started to increase. Furthermore, this phase definitely differed from what is seen normally, with a greater increase and a prolonged retention of the glycerides in the blood stream, indicative of a decreased removal rate of the alimentary chylomicrons in this patient even when the plasma lipids were at their lowest value during the hepatitis.

The possibility that the metabolism of endogenously derived glycerides was altered is suggested by 1) the fact that in spite of the greatly decreased glyceride level no major influence was observed on the metabolism of exogenous glycerides, and 2) the close parallelism between the cholesterol and glyceride levels during the disease. The blood cholesterol is known to be synthesized in the liver and the above-mentioned close parallelism between the two types of lipids might suggest that the liver damage per se had caused a decreased synthesis of triglyceride-rich lipoproteins. It is of interest in this connection that a decrease of the $S_{f} 100$ to 400 classes of lipoproteins, known to be very rich in triglyceride (45), has been reported in hepatitis (46) although the total level of glycerides seemingly is not decreased (47).

The findings in this case of essential hyperlipemia have indicated that the lipoprotein lipase 
system (lipemia clearing factor system) is intact upon heparin administration while on the other hand the metabolism and transport of endogenously derived glycerides is definitely changed from the normal state. This is of great practical, as well as theoretical, interest in view of the fact that cases of essential hyperlipemia with defective lipoprotein lipase system and normal metabolism of endogenous glycerides have been reported $(8,23)$.

\section{SUMMARY}

A case of essential hyperlipemia was studied with special reference to the serum glycerides. The main findings were as follows.

1. The serum glycerides were greatly increased. The percentage composition of tri-, di- and monoglycerides was normal. Total cholesterol and phospholipids were moderately elevated and the unesterified fatty acids slightly increased.

2. Starvation for four days reduced the serum glycerides and increased the unesterified fatty acids. The glyceride level was, however, still 10 times above the normal value.

3. Heparin administration decreased the glyceride level. The response as regards partial glycerides was qualitatively normal.

4. In vitro incubation of the isolated, very low density lipoproteins with partly purified postheparin clearing factor resulted in an abnormally slow hydrolysis of the triglycerides.

5. Transfusion of the patient's plasma to a normal recipient revealed at least two exponential functions for the removal of the glycerides with half-lives of about 30 and 1,100 minutes.

6. During a viral hepatitis, the patient's milky plasma became almost clear. The principal findings in the blood lipid pattern during the hepatitis was a simultaneous, pronounced decrease of cholesterol and glycerides starting before any subjective symptoms had appeared. After healing of the hepatitis, the blood lipids started to increase.

\section{REFERENCES}

1. Addison, T., and Gull, W. Guy's Hosp. Rep. 1857, 7, 265. (Cited in Harris-Jones, J. N., Jones, E. G., and Wells, P. G. Xanthomatosis and essential hypercholesterolaemia. Lancet 1957, 1, 855.)

2. Bürger, M., and Grütze, $O$. Über hepatosplenomegale Lipoidose mit xanthomatösen Veränderungen in Haut und Schleimhaut. Arch. Derm. Syph. (Berl.) 1932, 166, 542.
3. Malmros, H., Swahn, B., and Truedsson, E. Essential hyperlipaemia. Acta med. scand. 1954, 149, 91.

4. Holt, L. E., Jr., Aylward, F. X., and Timbres, H. G. Idiopathic familial lipemia. Bull. Johns Hopk. Hosp. 1939, 64, 279.

5. Thannhauser, S. J., and Stanley, M. M. Serum fat curves following administration of $\mathrm{I}^{131}$ labeled neutral fat to normal subjects and those with idiopathic hyperlipemia. Trans. Ass. Amer. Phycns 1949, 62, 245.

6. Schrade, W., Becker, G., and Böhle, E. Das Krankheitsbild der idiopatischen Hyperlipidämie. Dtsch. Arch. klin. Med. 1954, 201, 344.

7. Martt, J. M., and Connor, W. E. Idiopathic hyperlipemia associated with coronary atherosclerosis. Arch. intern. Med. 1956, 97, 492.

8. Havel, R. J. Evidence for the participation of lipoprotein lipase in the transport of chylomicrons in Proc. Third int. Conf. on Biochemical Problems of Lipids (Brussels, 1956), p. 265.

9. Schettler, G., Eggstein, M., and Jobst, H. Die essentielle Hyperlipämie. Dtsch. med. Wschr. 1958, 83, 1.

10. Brown, R. K., Boyle, E., and Anfinsen, C. B. The enzymatic transformation of lipoproteins. J. biol. Chem. 1953, 204, 423.

11. Carlson, L. A., and Wadström, L. B. On the occurrence of tri-, di- and monoglycerides in human serum in Proc. Third int. Conf. on Biochemical Problems of Lipids (Brussels, 1956), p. 123.

12. Carlson, L. A., and Wadström, L. B. Determination of glycerides in blood serums. Clin. chim. Acta 1959, 4, 197.

13. Borgström, B. Investigation on lipid separation methods. Separation of cholesterol esters, glycerides and free fatty acids. Acta physiol. scand. 1952, 25, 111.

14. Hanel, H. K., and Dam, H. Determination of small amounts of total cholesterol by the Tschugaeff reaction with a note on the determination of lathosterol. Acta chem. scand. 1955, 9, 677.

15. Carlson, L. A., and Wadström, L. B. A colorimetric method of determining unesterified fatty acids in plasma. Scand. J. clin. Lab. Invest. 1958, 10, 407.

16. Carlson, L. A. Chromatographic separation of serum lipoproteins on glass powder columns in Proc. Third int. Conf. on Biochemical Problems of Lipids (Brussels, 1956), p. 113.

17. Nikkilä, E. Studies on the lipid-protein relationships in normal and pathological sera and the effect of heparin on serum lipoproteins. Scand. j. clin. Lab. Invest. 1953, 5, Suppl. 8.

18. Reinhold, J. G. Glucose in Standard Methods of Clinical Chemistry, Amer. Ass. of Clin. Chemists, M. Reiner, Ed. New York, Academic Press Inc., 1953, vol. 1, p. 65.

19. Meulengracht, E. J. Studier over den kroniske hereditaere haemolytiske ikterus (thesis). Copenhagen, 1918. 
20. Buch, I., and Buch, H. An improved King and Armstrong method for the determination of phosphatase activity in blood serum. Acta med. scand. 1939, 101, 211.

21. McLagan, N. F. The thymol turbidity test; new indicator of liver dysfunction. Brit. J. exp. Path. 1944, 25, 234.

22. Dole, V. P. A relation between non-esterified fatty acids in plasma and the metabolism of glucose. J. clin. Invest. 1956, 35, 150.

23. Havel, R. J., and Gordon, R. S., Jr. An enzymatic defect associated with altered lipoprotein metabolism in an individual with idiopathic hyperlipemia (abstract). Circulation 1955, 12, 485.

24. Laurell, S. Plasma free fatty acids in diabetic acidosis and starvation. Scand. J. clin. Lab. Invest. 1956, 8, 81.

25. Gordon, R. S., Jr. Unesterified fatty acid in human blood plasma. II. The transport function of unesterified fatty acid. J. clin. Invest. $1957, \cdot 37$, 810.

26. Van Eck, W. F., Peters, J. P., and Man, E. B. Significance of lactescence in blood serum. Metabolism 1952, 1, 383.

27. Klatskin, G., and Gordon, M. Relationship between relapsing pancreatitis and essential hyperlipemia. Amer. J. Med. 1952, 12, 3.

28. Joyner, C. R., Jr. Essential hyperlipemia. Ann. intern. Med. 1953, 38, 759.

29. Herzstein, J., Wang, C. I., and Adlersberg, D. Effect of heparin on plasma lipid partition in man: Studies in normal persons and in patients with coronary atherosclerosis, nephrosis and primary hyperlipemia. Ann. intern. Med. 1954, 40, 290.

30. Lever, W. F., Smith, P. A., and Hurley, N. A. Idiopathic hyperlipemia and primary hypercholesteremic xanthomatosis. II. Effects of intravenously administered heparin on the plasma proteins and lipids. J. invest. Derm. 1954, 22, 71.

31. Carlson, L. A., and Wadström, L. B. Studies on the glycerides during the clearing reaction. Clin. chim. Acta 1957, $2,9$.

32. Borgström, B., and Carlson, L. A. On the mechanism of the lipolytic action of the lipaemia-clearing factor. Biochim. biophys. Acta 1957, 24, 638.

33. Havel, R. J. Early effects of fasting and of carbohydrate ingestion on lipids and lipoproteins of serum in man. J. clin. Invest. 1957, 36, 855.
34. Havel, R. J., and Fredrickson, D. S. The metabolism of chylomicra. I. The removal of palmitic acid-1-C $\mathrm{C}^{14}$ labeled chylomicra from dog plasma. J. clin. Invest. 1956, 35, 1025.

35. French, J. E., Morris, B., and Robinson, D. S. Observations on the removal of chylomicra from the blood in Proc. Third int. Conf. on Biochemical Problems of Lipids (Brussels, 1956), p. 323.

36. Eder, H. A. The lipoproteins of human serum. Amer. J. Med. 1957, 23, 269.

37. Lever, W. F., Smith, P. A. J., and Hurley, N. A. Idiopathic hyperlipemic and primary hypercholesterolemic xanthomatosis. I. Clinical data and analysis of the plasma lipids. $\mathrm{J}$. invest. Derm. 1954, 22, 33.

38. Adlersberg, D., and Wang, C. I. Syndrome of idiopathic hyperlipemia, mild diabetes mellitus, and severe vascular damage. Diabetes 1955, 4, 210.

39. Munk, I. Über die Resorption von Fetten und festen Fettsäuren nach Ausschluss der Galle vom Darmkanal. Virchows Arch. path. Anat. 1890, 122, 302.

40. Shapiro, A., Koster, H., Rittenberg, D., and Schoenheimer, $R$. The origin of fecal fat in the absence of bile, studied with deuterium as an indicator. Amer. J. Physiol. 1936, 117, 525.

41. Gross, J. B., Comfort, M. W., Wollaeger, E. E., and Power, M. H. Total solids, fat and nitrogen in the feces. V. A study of patients with primary parenchymatous hepatic disease. Gastroenterology 1950, 16, 140.

42. Colwell, A. R., Jr. Fecal fat excretion in patients with jaundice due to viral hepatitis. Gastroenterology 1957, 33, 591.

43. Crandall, L. A., Jr., and Ivy, H. B. Bile salts and fat absorption (abstract). Amer. J. Physiol. 1940, 129, P341.

44. Borgström, B. On the mechanism of the intestinal fat absorption. V. The effect of bile diversion on fat absorption in the rat. Acta physiol. scand. 1953, 28, 279.

45. Bragdon, J. H., Havel, R. J., and Boyle, E. Human serum lipoproteins. I. Chemical composition of four fractions. J. Lab. clin. Med. 1956, 48, 36.

46. Pierce, F. T., Jr., Kimmel, J. R., and Burns, T. W. Lipoproteins in infectious and serum hepatitis. Metabolism 1954, 3, 228.

47. Albrink, M. J., Man, E. B., and Peters, J. P. Serum lipids in infectious hepatitis and obstructive jaundice. J. clin. Invest. 1950, 29, 781. 